\title{
The Impact of Green Marketing and Perceived Innovation on Purchase Intention for Green Products
}

\author{
Shwu-Ing $\mathrm{Wu}^{1} \&$ Yen-Jou Chen ${ }^{1}$ \\ ${ }^{1}$ Department of Business Administration, National Chin-Yi University of Technology, Taiwan, R.O.C. \\ Correspondence: Professor Shwu-Ing Wu, Department of Business Administration, National Chin-Yi University \\ of Technology, No.57, Section 2, Chungshan Road, Taiping, Taichung, Taiwan 411, R.O.C. Tel: \\ 886-4-2392-4505. E-mail: wusi@ncut.edu.tw
}

Received: August 1, $2014 \quad$ Accepted: September 4, $2014 \quad$ Online Published: September 28, 2014
doi:10.5539/ijms.v6n5p81
URL: http://dx.doi.org/10.5539/ijms.v6n5p81

\begin{abstract}
With the rise of eco-awareness and innovation in recent years, companies have constantly sought to be the first to introduce new green-concept products to the market to gain a larger market share. However, it is unclear whether consumer awareness of green marketing and innovation will increase purchase intention. This issue requires an in-depth discussion. This study uses energy-saving lamps and environmental cleanser as examples, using a literature review and empirical research to explore the correlations between consumer awareness of green marketing, perceived innovation, perceived quality, perceived price, perceived risk, perceived value, and purchase intention. Further, an overall relationship model is established.

An analysis of 320 effective questionnaires about energy-saving lamp and 310 effective questionnaires about an environmental cleanser resulted in three main findings: (1) Consumers' green marketing awareness of both energy-saving lamp and an environmental cleanser mainly influences their perceived quality and perceived value, which in turn influence purchase intention. (2) Consumers' perceived innovation of energy-saving lamp mainly influences their perceived quality, perceived price, and perceived value, while consumers' perceived innovation of an environmental cleanser mainly influences their perceived quality and perceived value, all of which in turn influence purchase intention. (3) The results for the two products indicate that the impact of consumers' green marketing awareness on purchase intention is greater than the impact of perceived innovation. Through SEM analysis, this study establishes a valid relationship model for green products and identifies the main influence paths. In addition, measurement variables and a scale were established, which provide academics and industry with critical research tools and concepts that should be of academic and practical value.
\end{abstract}

Keywords: green marketing awareness, perceived innovation, perceived quality, perceived price, perceived risk, perceived value, purchase intention

\section{Introduction}

The green industry has become popular in recent years. With an increase in the public's environmental awareness, the trend of green consumption is moving into the market mainstream. Most people in developed countries regard environmental protection as an important factor in purchase decisions (Peattie, 1992). Therefore, most companies offer green products to meet and satisfy consumer requirements and conduct green marketing initiatives to drive green consumption. Green marketing suggests that the entire lifecycle of a product, from materials acquisition, production, sale, and consumption, to the disposal of waste, has a minimum impact on the environment (Charter, 1991). It is a marketing model that puts the environmental protection concept into the product design, production, and service process ( $\mathrm{Tu}, 2002)$. Therefore, green marketing is an indispensable strategy for companies involved in market competition. Meanwhile, consumer are actively trying to reduce their impact on the environment, however, this is not widespread and is still evolving (Cherian \& Jacob, 2012). Therefore, the question of whether consumer awareness the green marketing performed by companies and whether which will increase consumer's purchase intention that requires an in-depth discussion.

In addition to green consciousness, innovation is another important aspect that influences consumers' purchase intention and market performance (Pujari, 2006). Meanwhile, green marketing as an opportunity for innovation (Ottman, 2013). Freeman (1982) proposed that "not to innovate is to die"; this means innovation will influence enterprise growth and determine whether or not an enterprise will survive. Thus, a company must constantly 
innovate in order to survive in a competitive environment (Porter \& Van, 1995). Hurley and Hult (1998) found that almost all industries engaged in innovative activities in a dynamic market. However, the question of how the companies' innovation strategies are perceived by consumers and how effective they are requires further exploration.

Many scholars studied green marketing and innovation separately, such as: Charter (1991), Peattie (1992), and Prakash (2002) investigated the topic of green marketing; Vrakking (1990) and Higgins (1995) studied innovation issue. But, few studies have discussed the combination of both issues. However, a key question when focusing on green products is what is the consumer's perception? Is the item a green product or an innovative product? Which one is more important in influencing consumers' purchase intention? These issues are few been discussed simultaneously.

In addition to green marketing and innovation aspects, there are the between-antecedent (that is, green marketing and innovation aspects) mediator variables and consequence variables (such as purchase intention). Monroe and Krishnan (1985) proposed that consumer perception of product price is an indicator of perceived quality and perceived sacrifice, and perceived value can be obtained by comparing the perceived quality and perceived sacrifice. This perceived value affects purchase intention. On the other hand, higher perceived risk will hinder consumers' purchase intention? In light of the above, this study aims to investigate the impact of green marketing awareness and perceived innovation of green products on purchase intention. At the same time, the perceived factors, including perceived quality, perceived price, perceived risk, and perceived value are all used as mediator variables to establish a full relationship model. Furthermore, we compare the effect of green marketing awareness and perceived innovation.

Obviously, using energy-saving lamps will be the trend in the future. Due to energy-saving lamp can save energy and reduce carbon dioxide emissions. Therefore, energy-saving lamps are selected as a study object. On the other hand, a survey done by Shelton Group Eco Pulse showed that the green products consumers most want to buy are household cleaning products (75\%) (Green Business News, 2010). Thus, an environmental cleanser is another product selected for this study. Both of these two products are meet the definition of green product by Ottman, Stafford \& Hartman (2006) and Dangelico \& Pontrandolfo (2010). They proposed that the main types of environmental focus of green product development, namely energy, resources, reducing pollution and waste. Consumers in Taiwan were interviewed to explore their perceptions about green marketing and innovation toward energy-saving lamp and environmental cleanser, and their perceived quality, perceived price, perceived risk, perceived value and purchase intention focus on these two green products.

\section{Literature Review and Research Hypotheses}

\subsection{Consumer's Green Marketing Awareness and Perceived Quality}

Green marketing is an organized environmental protection campaign that the general public cares about because it improves the environment (Kotler \& Armstrong, 2008). Grewal and Levy (2008) proposed that green marketing provides consumers with more eco-friendly products through strategies employed by the relevant enterprises. Therefore, green marketing can more protect environment than general marketing methods (Gail, 2010). Polonsky (2011) defined green marketing as that all activities designed by companies in order to satisfy human needs or wants with minimal detrimental impact on the natural environment. Consumer's green marketing awareness means consumer aware that green marketing covers the overall brand of marketing activities undertaken by companies in a manner that they promote manufacture of products or service operation which have a positive impact on environment or alternatively reduce negative impact on the environment (Cherian \& Jacob, 2012). Chen and Kao (2005) addressed six dimensions for green marketing evaluation: green products, green manufacturing and packaging, green design, green promotion, green enterprises, and green consumption. The indictors for measuring consumers' green marketing awareness in this study are designed based on these six dimensions of Chen and Kao (2005).

Perceived quality means evaluates consumer perception on the quality of a product (Tsiotsou, 2006); represents consumers' overall judgment on the superiority of a product (Zeithaml, 1988). Perceived quality is influenced by consumers' subjective perception and environmental contexts (Zeithaml \& Bitner, 2000). In this study, perceived quality is measured using the four dimensions of Petrick (2002): superiority, consistency, dependability, and reliability, since these can be used to measure consumers' overall judgment of a product or service.

When consumer aware a company performs green marketing that can increases consumers' perception of high quality, purchase intention, and environmental perception of the products (Lin, 1996). Ottman (1999) pointed out that the goals of green marketing are as follows: (1) products should be developed to satisfy consumers in quality, function, price, and convenience as well as influence the environment the least; (2) products should establish a 
high-quality image. Hence, the one of the fundamental reason for consumers to purchase green products lies in the expectation of high quality in green products. Hendershot (2009) proposed that green products provide high quality and high efficiency and offer consumers extra benefits, such as being healthier. Simon (1992) proposed that the quality of a green product is better than others. Thus, consumers will perceive the quality positively if they feel a product has green marketing characteristics. However, Drumwright (1998) point out that consumers felt green goods were lower quality and impede purchase that need further explore. Therefore, the following hypothesis is established:

H1: Green marketing awareness by consumer toward a green product has a positive influence on consumer's perceived quality.

\subsection{Green Marketing Awareness and Perceived Price}

Perceived price is a feeling that consumers have about the price of a product; it is an overall concept including the paid currency and non-currency costs (Zeithaml, 1988). Generally, it is difficult for consumers to remember the actual price of a product, so the actual price is transferred into one concept. For example, "cheap" indicates a low price or better value, whereas "expensive" indicates a high price or goods cost more; these perceptions, which easily stay in one's memory, indicate the so-called perceived price (Kashyap \& Bojanic, 2000). Petrick (2002) proposed six indexes to measure consumers' perceived price: an excellent purchase, equivalent value, above the value, reasonable price, economic, and a fine trade. These indexes were used to design the measurement items for consumers' perceived price in this study.

Kassarjian (1971) discovered that consumers' concern about environmental pollution was a crucial variable that made them willing to purchase green products with a higher price. MacKenzie (2000) found that $75 \%$ of Americans were willing to purchase green products with a higher price. The TNS Global Market Research investigation found that $52 \%$ of people in Taiwan were willing to pay extra money for green products (TNS, 2008). Green Gauge's study discovered that $74 \%$ of consumers thought that green products were worth higher prices (Makower, 2009). Boston Consulting Group's investigation showed that $82 \%$ of consumers were willing to pay more for green products (Hendershot, 2009). It is thus obvious that most people in various countries are willing to spend extra money for green products. Thus, consumers tend to have higher price perception toward the green products (Leonidou, Katsikeas \& Morgan, 2012). Therefore, the following hypothesis is established:

H2: Green marketing awareness by consumer toward a green product has a positive influence on consumer's perceived price.

\subsection{Green Marketing Awareness and Perceived Risk}

Perceived risk indicates consumers' uncertainty about the outcomes of individual purchase, use, or disposal behavior (Hoyer \& Macinnis, 2010). Any uncertainty or unfavorable result that consumers perceive is subjectively an expected loss (Sweeney, Soutar, \& Johnson, 1999). Perceived risk can be defined as the characteristics and sum of the risk that consumers expect from particular purchase behavior (Lim, 2003). Consumers' perceived risk is multi-dimensional (Roselius, 1971). Jacoby and Kaplan (1972) divided consumers' perceived risk into five categories: financial risk, performance risk, physical risk, psychological risk, and social risk. Kaplan (1974) further proved that these five types of risk could be used to explain the overall concept of consumers' perceived risk. Hence, this study uses these five categories to measure consumers' perceived risk.

Since green marketing provides consumers with more eco-friendly products (Grewal \& Levy, 2008), it is an organized campaign that protects the general public and improves the environment (Kotler \& Armstrong, 2008). Bjorner et al. (2004) pointed out that the implementation of green marketing can help consumers identify environmentally friendly products and form a basis for buying green products, which can also reduce consumer uncertainty. Therefore, consumers will perceive that green products have more value and reduce their perceived risk (Gail, 2010; Leonidou, Katsikeas, \& Morgan, 2012). Thus, the high green marketing awareness by consumer, will reduced consumer's perceived risk. Therefore, the following hypothesis is established:

H3: Green marketing awareness by consumer toward a green product has a negative influence on consumer's perceived risk.

\subsection{Green Marketing Awareness and Perceived Value}

Zeithaml (1988) defined consumers' perceived value as the overall evaluation consumers made of a product based on their gains and what they paid. Sheth, Newman, and Gross (1991) proposed five types of perceived value - functional value, social value, emotional value, epistemic value, and conditional value - which further influence consumers' selection. Moreover, Sweeney and Soutar (2001) classified perceived value into four dimensions: emotional, social, quality/performance, and price/monetary. These dimensions were referred to in 
the design of the measurement items for perceived value in this study.

The motive for consumers to purchase green products is that green products provide extra value, such as high security and environmental protection (Manget, 2009). If consumers perceive the functions and effects of green goods, their perceived value of green marketing will definitely improve (Yan \& Chang, 2006). To take energy-saving lamps as an example, if consumers think that these lamps can save energy and reduce carbon emissions in ways that meet the principles of environmental protection, such as reducing, reusing, and recycling, they will think purchasing energy-saving lamps is valuable behavior (Chang, 2005). Thus, the greater consumers' perception of a product's green marketing, the higher the perceived value is. Therefore, the following hypothesis is established:

H4: Green marketing awareness by consumer toward a green product has a positive influence on consumer's perceived value.

\subsection{Green Marketing Awareness and Purchase Intention}

Purchase intention indicates an emotional reaction resulting from consumers' overall evaluation of a product, and also indicates the possibility that consumers would like to purchase the product (Grewal, Monroe, \& Krishnan, 1998). Purchase intention is the most precise predictor of purchase behavior (Morwitz \& Schmittlein, 1992).

Zeithaml (1988) proposed three indexes - the possibility that consumers will purchase the product, whether they consider buying the product, and whether they will recommend the product to their relatives and friends - as the variables for measuring purchase intention. Dodds, Monroe, and Grewal (1991) raised items for measuring purchase intention, including purchase possibility, purchase price, purchase probability, and purchase intention. Bei and Yu (2001) measured consumers' purchase intention using two major items: re-purchase and recommending the item to other consumers. The above indexes were used in the development of the measurement variables for purchase intention in this study.

Balderjahn (1988) found that consumers possessing a positive attitude about environmental protection would purchase and use more green products. Consumers begin to value environmental issues gradually and consequently become more willing to purchase green products (Loudon \& Bitta, 1988). Greenseal (2009) found that most consumers were still willing to purchase green products even in an economic downturn. Burst Media's (2010) investigation showed that consumers believing in the green concept were willing to spend more money to purchase green organic products. Environmental advertisements and Ecological packaging are positively related with the green purchase intention (Ansar, 2013). Therefore, the following hypothesis is established:

H5: Green marketing awareness by consumer toward a green product has a positive influence on consumer's purchase intention.

\subsection{Perceived Innovation and Perceived Quality}

An "innovation" indicates any new product, service, or creative element considered to be novel, including technological improvements, new changes to products and production, and new marketing methods (Porter, 1990). Innovation also represents updates to design that distinguish an organization from its competitors (Vrakking, 1990). De Brentani (2001) addressed that innovation indicates the degree of developing new products or gradual improvement, and simultaneously took into account novelty in technologies and markets.

Higgins (1995) classified innovation into four types: product innovation, procedure innovation, marketing innovation, and management innovation. Betz (2003) divided innovation into product innovation, manufacturing process innovation, and service innovation. Rogers (1995) argued that innovation has five features: relative advantage, compatibility, complexity, trialability, and observability. He suggested these features are identified by consumers as perceived innovation. Therefore, perceived innovation is a required measure based on the consumer viewpoint.

Kwaku (1995) found that the more curious consumers felt about an innovative product, the more they would recognize any improvement in its quality, functions, and benefits. Roberston (1985) argued that compared with existing products, innovative products provide greater value and quality. Ottenbacher and Gnoth (2005) addressed that innovation could improve the quality of products and attract potential customers to purchase. Therefore, this study proposes the following hypothesis:

H6: Consumers perceptions on product innovation will positive influence on consumer's perceived quality.

\subsection{Perceived Innovation and Perceived Price}

When introduce an innovative product, many companies take a high pricing, so the prices of innovative products are usually higher (Kotler \& Armstrong, 2008). Furthermore, most consumers think that innovative products 
have new functions or better utility, so their prices will be relatively higher (OECD, 2009). Since consumers interested in an innovative product tend to like exciting and novel things, they are willing to take risks and pay more (Roger, 1995). NPD (2010) investigated consumers' perception and attitudes about innovative products and also found that consumers thought innovative products were worth higher prices. Therefore, this study proposes the following hypothesis:

H7: Consumers perceptions on product innovation will positive influence on consumer's perceived price.

\subsection{Perceived Innovation and Perceived Risk}

Ram (1987) showed that consumers might deny the existence of innovation, and innovation resistance originated from consumers' normal response based on this instinct. When consumers perceive risk due to functional or mental obstacles, they try to delay the adoption of innovation (Ram \& Sheth, 1989). Rogers (1995) argued that not all innovations would be accepted positively; there could be obstacles that cause consumers to refuse to purchase innovative products.

Sheth (1981) considered that innovation resistance mainly came from the consumer's behavioral habits and the perceived risk of adopting innovation. Ram (1989) brought up three factors of innovation resistance: risk, the necessity for more information, and the previous structure of faith. All these obstacles increase consumers' perceived risk of innovative products. Therefore, this study proposes the following hypothesis:

H8: Consumers perceptions on product innovation will positive influence on consumer's perceived risk.

\subsection{Perceived Innovation and Perceived Value}

Rogers (1995) proposed that the influence of innovation on consumers included the advance of relative predominance, that is, product innovation brings consumers positive value. Flint et al. (1997) argued that customer value would improve due to the influence of critical events, such as technological and service innovations. Bourdeau et al. (2002) also proved that consumers advanced each type of value while using innovative technology. Weerawardena (2003) addressed that innovation gradually improves products, production, service, and marketing systems to increase customer value. Tsai et al. (2010) discovered that developing new products and new services positively influences consumers' expectations and satisfaction and further enhances customer value. Therefore, this study proposes the following hypothesis:

H9: Consumers perceptions on product innovation will positive influence on consumer's perceived value.

\subsection{Perceived Innovation and Purchase Intention}

Innovative products should bring consumers more value in order to increase their acceptance and raise their purchase intention (Holak, 1988). Boyd and Mason (1999) found that the attraction of innovation influenced consumers' attitudes and tendencies, which further influences their purchase intention.

Holak and Lehmann (1990) pointed out that the predominance of a product more innovative than previous products could be regarded as an index of related product benefits, that is, of the major concerns for enhancing consumers' purchase of innovative products. Horn and Salvendy (2006) found that if consumers were provided more detailed information on innovative products, their purchase intention would be positively stimulated. Therefore, this study proposes the following hypothesis:

H10: Consumers perceptions on product innovation will positive influence on consumer's purchase intention.

\subsection{Perceived Quality and Perceived Value}

Generally, higher perceived quality generates higher perceived value (Monroe \& Krishnan, 1985; Zeithaml, 1988). Hence, when perceived quality is greater than perceived sacrifice, consumers have positive perceived value. A positive relationship thus exists between perceived quality and perceived value.

According to Chen and Dubinsky (2003) and Grewal et al. (1998), the value that consumers gain is mainly the benefit obtained from product quality. The greater the product quality consumers perceive, the higher is the perceived value. Therefore, this study proposes the following hypothesis:

H11: Consumer's perceived quality toward a green product has a positive influence on consumer's perceived value.

\subsection{Perceived Quality and Purchase Intention}

Chaudhuri (2002) considered perceived quality to be an important factor in consumers' satisfaction, in that the higher perceived quality consumers had, the higher their purchase intention was. Zeithaml's (1988) causal relation model showed that consumers' purchase intention depended on perceived value, and perceived value 
came from perceived quality, so the increase of perceived quality increased consumers' purchase intention. Dodds et al. (1991) also discovered that perceived quality positively influenced perceived value, and perceived value also positively influenced purchase intention. Petrick (2004) found that when the perceived quality of a product was high, the perceived value would be high, and the purchase intention would also increase. Tsiotsou (2006) further proved that perceived quality and purchase intention were directly positively correlated, so perceived quality could be used in predicting purchase intention. Therefore, this study proposes the following hypothesis:

H12: Consumer's perceived quality toward a green product has a positive influence on consumer's purchase intention.

\subsection{Perceived Price and Perceived Value}

Bruce and Abhijit (2002) indicated that when consumers perceive that a price is high, they feel what they paid is more than what they gained, so the perceived value decreases. Therefore, they proved that perceived price has a direct negative influence on perceived value (Oh, 1999; Tam, 2004). Previous research has also found that price has a direct negative influence on perceived value (Dodds et al., 1991; Sweeney, Soutar \& Johnson, 1999). Therefore, this study proposes the following hypothesis:

H13: Consumer's perceived price toward a green product has a negative influence on consumer's perceived value.

\subsection{Perceived Price and Purchase Intention}

Tsai and Lee (1999) argued that perceived price indicates consumers' sensitivity to price variation: people with greater price perception were described as being less willing to purchase products.

Suter and Hardesty (2005) pointed out that consumers' perceived price has significant influence on their purchase intention. When the price of a product is obviously high, consumers think they are treated unfairly, and the purchase intention decreases (Maxwell, 2001; Babin, Hardesty \& Suter, 2003). Therefore, this study proposes the following hypothesis:

H14: Consumer's perceived price toward a green product has a negative influence on consumer's purchase intention.

\subsection{Perceived Risk and Perceived Value}

Wood and Scheer (1996) regarded perceived risk as a necessary cost to obtain a product that influences the perceived value through overall trade evaluation. Agarwal and Teas (2001) suggested that a significantly negative relation exists between perceived risk and consumers' perceived value. Tsai, Lee, and Wu (2004) and Wood and Scheer (1996) discovered that for consumers, perceived risk is an invisible cost when purchasing products, and it has direct negative influence on perceived value. When consumers make purchase decisions, they evaluate risk, and when their perceived risk of a product is high, their perceived value of the product is lowered (Sweeney et al., 1999). Therefore, this study proposes the following hypothesis:

H15: Consumer's perceived risk toward a green product has a negative influence on consumer's perceived value.

\subsection{Perceived Risk and Purchase Intention}

When consumers cannot predict purchase results and feel uncertain, perceived risk exists in their decision-making process (McKnight et al., 2002). Bettman (1973) argued that consumers' purchase intention is influenced negatively by perceived risk. Roselius (1971) pointed out that when encountering perceived risk, consumers usually have diversified reactions, one of which is to delay the purchase behavior in order to transfer the loss.

Taylor (1974) considered that before purchasing, consumers perceive the risk a product could generate; this type of risk reduces consumers' purchase impulse because they want to avoid unpleasantness after the purchase. Shimp and Bearden (1982) and Garretson and Clow (1999) also found that when consumers have high perceived risk, their purchase intention is reduced. Therefore, this study proposes the following hypothesis:

H16: Consumer's perceived risk toward a green product has a negative influence on consumer's purchase intention.

\subsection{Perceived Value and Purchase Intention}

Fornell, Johnson, Anderson, Cha, and Bryant (1996) pointed out that consumers are influenced by perceived value when they purchase products. Thus, consumers' purchase intention depends on their perceived value of a product, which indicates a positive association between perceived value and purchase intention (Zeithaml, 1988; 
Grewal et al., 1998).

Kaufman (1998) considered that perceived value could be used to discover customers' desire, demand, and exchange value for goods or services when deciding whether or not to purchase. Perceived value is consumers' subjective perception; it is relevant to consumers' emotional response and consumption experience and further influences consumer behavior (Dumana \& Mattilab, 2005). Rizwan et al. (2013) found that green perceived value is positively associated with green purchase intention. Since the value of a product in a consumer mind will establish a trust and therefore the consumers' purchasing behavior will also be encouraged. Thus, high perceived value increases consumers' purchase intention (Bellizzi, 1981). Therefore, this study proposes the following hypothesis:

H17: Consumer's perceived value toward a green product has a positive influence on consumer's purchase intention.

\section{Research Design}

\subsection{Research Framework}

To summarize the literature review and research hypothesis, this study establishes the research framework depicted in Figure 1. This study is the first to explore two independent variables - green marketing awareness and perceived innovation; how these independent variables affect the mediator variables of perceived quality, perceived price, perceived risk, and perceived value; and further how to affect the dependent variable, purchase intentions.

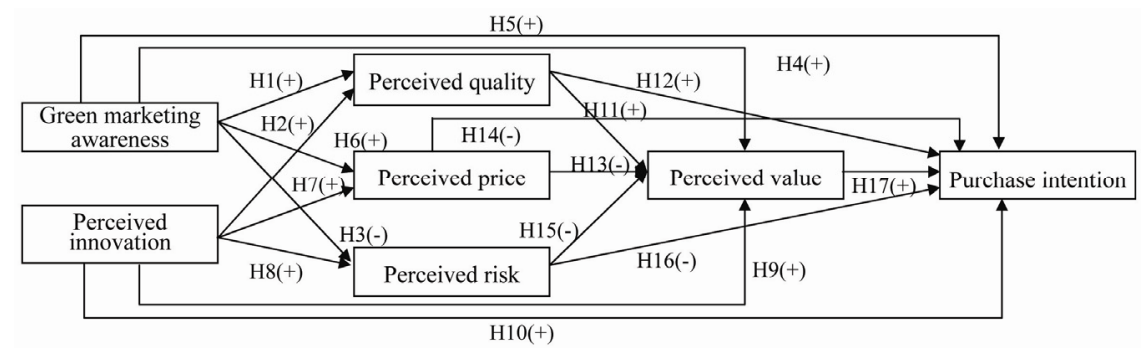

Figure 1. Research framework

\subsection{Questionnaire Design}

The self-completion questionnaire is "a questionnaire that the respondent answers without the aid of an interviewer" (Bryman \& Bell, 2011). Thus the respondents cannot be influenced by the interviewer; their answers should be more objective. A questionnaire is "a formalized framework consisting of a set of questions and scales designed to generate primary data" (Shiu et al., 2009). As said previously a self-completion questionnaire seems to be the best approach for the quantitative method.

Therefore, the related literature and measurement items were first used as a reference for the design of the draft questionnaire. The questionnaire is divided into eight sections: green marketing awareness (reference from Chen and Kao (2005)), perceived innovation (reference from Betz (2003)), perceived quality (reference from Petrick (2002)), perceived price (reference from Petrick (2002)), perceived risk (reference from Kaplan (1974)), perceived value (reference from Sweeney and Soutar (2001)), and purchase intention (reference from Dodds, Monroe, and Grewal (1991)and Bei and Yu (2001)); all were evaluated with a seven-point Likert scale, where a higher score indicates stronger agreement. There is also a final section that records demographics using a nominal scale.

Next, a pretest was administered to determine the necessary modifications. In this step, 30 consumers were selected through convenience sampling for interviews. The results showed that some of the questions were ambiguous and required revisions that were incorporated.

After modification, convenience sampling was applied again to pick 50 interviewees for each product - energy-saving lamps and an environmental cleanser - to perform the pilot test. The modified questions were answered, and reliability and validity were analyzed. After reliability and validity testing, two perceived risk items for both products with factor loading lower than 0.6 and correlation coefficients of item-to-total lower than 0.5 were removed, and the analysis was performed again. The results revealed that the Cronbach's $\alpha$ value 
of each measurement aspect exceeded 0.7 and the item-to-total correlations coefficient was larger than 0.5 that show the good reliability (Nunnally, 1978). The factor analysis show that the eigenvalue of each measurement factor was larger than 1 , the cumulative explained variance of each measurement factor was higher than 0.5 , the factor loading of each question was larger than 0.6, which show that all of the measurement dimensions have convergent validity (Kaiser, 1958; Kerlinger, 1978). Hence, the remaining items were used as the formal questionnaire for a large-scale survey.

\section{Research Results and Discussion}

\subsection{Sampling}

In this study, Taiwanese consumers older than 20 years were selected as the main interviewees. The sample size was calculated using the concept of probability sampling. This study assumed that tolerable error(e) is $5 \%$, population proportion $(\mathrm{P})$ is 0.5 , and confidence interval is $95 \%(\mathrm{Z}=1.96)$. Then the formula of sample size shown as: $\mathrm{Z}^{2} * \mathrm{P} *(1-\mathrm{P}) / \mathrm{e}^{2}=(1.96)^{2} * 0.5 *(1-0.5) /(0.05)^{2}=384.16$. Therefore, 385 is a suitable sample size of questionnaire. Beside, Boomsma \& Hoogland (2001) defined that 400 is the best and appropriate of the sample size, so we take 400 questionnaires as our sample size.

Convenience sampling is a sampling technique that obtains and collects the relevant information from sampling is normally used for collecting a large number of completed surveys speedily and with economy. Through a convenience sampling method, 400 interviewees were selected for each product. After two months, we received 630 valid questionnaires; 320 dealt with energy-saving lamp and 310 dealt with the environmental cleanser.

The sample structure shows that the two groups of respondents had similar backgrounds. The major characteristics of the two groups (energy-saving lamps and environmental cleanser) were that most respondents were female $(60.9 \%, 61.9 \%)$, aged $21-30(39.1 \%, 37.4 \%)$, college graduates $(52.5 \%, 50.6 \%)$, and single $(67.2 \%$, $64.8 \%$ ), and that the main reason they purchase green products is because they want to be environmentally friendly $(85.0 \%, 85.8 \%)$.

\subsection{Reliability and Validity Analysis}

The Cronbach's $\alpha$, correlation, and factor analyses were applied to evaluate the reliability and validity of the valid questionnaires. The results show that the Cronbach's $\alpha$ of each measurement is greater than 0.7 , which means the reliability of each measurement is high (Nunnally, 1978). The validity analysis results show that the eigenvalues of the measurement factors are greater than 1 , the cumulative explained variances are all greater than 0.5 , the factor loadings are all greater than 0.5 , and the correlation coefficients of item-to-total are all greater than 0.5 (as shown in Tables 1 and 2), which means that all of the measurement dimensions have convergent validity (Kaiser, 1958; Kerlinger, 1978).

Table 1. Reliability and validity analysis—Energy-Saving Lamp

\begin{tabular}{|c|c|c|c|c|c|}
\hline Items & $\begin{array}{l}\text { Item-total } \\
\text { correlation } \\
\text { coefficients }\end{array}$ & $\begin{array}{l}\text { Factor } \\
\text { loading }\end{array}$ & Eigenvalue & $\begin{array}{l}\text { Cumulative } \\
\text { explained } \\
\text { variance } \%\end{array}$ & $\begin{array}{l}\text { Cronbach's } \\
\alpha\end{array}$ \\
\hline \multicolumn{6}{|l|}{ Green marketing awareness } \\
\hline Energy-Saving Lamp can reduce environmental pollution & 0.674 & 0.765 & \multirow[t]{8}{*}{4.904} & \multirow[t]{8}{*}{61.304} & \multirow[t]{8}{*}{0.909} \\
\hline Energy-Saving Lamp is a green product & 0.782 & 0.850 & & & \\
\hline $\begin{array}{l}\text { The production of Energy-Saving Lamp can reduce the waste of } \\
\text { resources }\end{array}$ & 0.721 & 0.799 & & & \\
\hline Energy-Saving Lamp meet the concept of carbon reduction & 0.783 & 0.851 & & & \\
\hline $\begin{array}{l}\text { Energy-Saving Lamp comply with environmental protection } \\
\text { concept }\end{array}$ & 0.623 & 0.702 & & & \\
\hline $\begin{array}{l}\text { Energy-Saving Lamp enable consumers pay attention on } \\
\text { environmental issues }\end{array}$ & 0.587 & 0.665 & & & \\
\hline Energy-Saving Lamp can meet social responsibility & 0.719 & 0.792 & & & \\
\hline Using Energy-Saving Lamp is right behavior & 0.750 & 0.820 & & & \\
\hline \multicolumn{6}{|l|}{ Perceived innovation } \\
\hline Energy-Saving Lamp is a improvement product & 0.658 & 0.757 & \multirow[t]{5}{*}{4.650} & \multirow[t]{5}{*}{51.671} & \multirow[t]{5}{*}{0.881} \\
\hline Energy-Saving Lamp has innovation concept & 0.729 & 0.812 & & & \\
\hline The function of Energy-Saving Lamp has great difference & 0.567 & 0.659 & & & \\
\hline Energy-Saving Lamp has different design & 0.594 & 0.686 & & & \\
\hline Energy-Saving Lamp can saving more & 0.549 & 0.633 & & & \\
\hline
\end{tabular}




\begin{tabular}{|c|c|c|c|c|c|}
\hline The cleaning effect of Energy-Saving Lamp will stronger & 0.570 & 0.659 & & & \\
\hline Energy-Saving Lamp has a creative promotion method & 0.741 & 0.812 & & & \\
\hline Energy-Saving Lamp can attracting consumer & 0.581 & 0.682 & & & \\
\hline The innovation idea of Energy-Saving Lamp is outstanding & 0.651 & 0.744 & & & \\
\hline \multicolumn{6}{|l|}{ Perceived quality } \\
\hline The quality of Energy-Saving Lamp is superior & 0.775 & 0.860 & \multirow[t]{5}{*}{3.913} & \multirow[t]{5}{*}{78.268} & \multirow[t]{5}{*}{0.929} \\
\hline The quality of Energy-Saving Lamp is stable & 0.880 & 0.931 & & & \\
\hline The quality of Energy-Saving Lamp is reliability & 0.860 & 0.920 & & & \\
\hline The quality of Energy-Saving Lamp is high & 0.880 & 0.929 & & & \\
\hline The quality of Energy-Saving Lamp is effective & 0.670 & 0.772 & & & \\
\hline \multicolumn{6}{|l|}{ Perceived price } \\
\hline The price of Energy-Saving Lamp is expensive & 0.840 & 0.923 & \multirow[t]{4}{*}{3.023} & \multirow[t]{4}{*}{75.566} & \multirow[t]{4}{*}{0.890} \\
\hline The price of Energy-Saving Lamp is costly & 0.858 & 0.932 & & & \\
\hline $\begin{array}{l}\text { The price of Energy-Saving Lamp is higher than the ordinary } \\
\text { cleanser }\end{array}$ & 0.662 & 0.801 & & & \\
\hline The price of Energy-Saving Lamp is higher than my expected & 0.680 & 0.812 & & & \\
\hline \multicolumn{6}{|l|}{ Perceived risk } \\
\hline I am afraid that Energy-Saving Lamp is unvalued & 0.682 & 0.792 & \multirow[t]{6}{*}{3.890} & \multirow[t]{6}{*}{64.840} & \multirow[t]{6}{*}{0.891} \\
\hline I am afraid that Energy-Saving Lamp cannot meet the expectation & 0.721 & 0.820 & & & \\
\hline I am afraid that Energy-Saving Lamp cannot ensure its safety & 0.698 & 0.792 & & & \\
\hline I am afraid that Energy-Saving Lamp can not to protect my health & 0.723 & 0.811 & & & \\
\hline I am afraid that Energy-Saving Lamp is useless & 0.706 & 0.798 & & & \\
\hline I am afraid that Energy-Saving Lamp is ineffectiveness & 0.730 & 0.818 & & & \\
\hline \multicolumn{6}{|l|}{ Perceived value } \\
\hline Energy-Saving Lamp give me extra value & 0.757 & 0.844 & \multirow[t]{5}{*}{3.801} & \multirow[t]{5}{*}{76.015} & \multirow[t]{5}{*}{0.921} \\
\hline It's worth to pay more money for Energy-Saving Lamp & 0.799 & 0.875 & & & \\
\hline Energy-Saving Lamp have high utility & 0.821 & 0.891 & & & \\
\hline Energy-Saving Lamp can meet my requirements & 0.820 & 0.890 & & & \\
\hline Energy-Saving Lamp give me more benefits than the costs & 0.777 & 0.859 & & & \\
\hline \multicolumn{6}{|l|}{ Purchase intention } \\
\hline I like to purchase Energy-Saving Lamp & 0.765 & 0.851 & \multirow[t]{5}{*}{3.799} & \multirow[t]{5}{*}{75.892} & \multirow[t]{5}{*}{0.921} \\
\hline I will pay more money on Energy-Saving Lamp & 0.784 & 0.866 & & & \\
\hline I will take Energy-Saving Lamp as a first consideration & 0.800 & 0.877 & & & \\
\hline I will repeat purchasing Energy-Saving Lamp & 0.881 & 0.930 & & & \\
\hline I will recommend other people to purchase Energy-Saving Lamp & 0.739 & 0.831 & & & \\
\hline
\end{tabular}

Table 2. Reliability and validity analysis-Environmental Cleanser

\begin{tabular}{|c|c|c|c|c|c|}
\hline Items & $\begin{array}{l}\text { Item-total } \\
\text { correlation } \\
\text { coefficients }\end{array}$ & $\begin{array}{l}\text { Factor } \\
\text { loading }\end{array}$ & Eigenvalue & $\begin{array}{l}\text { Cumulative } \\
\text { explained } \\
\text { variance } \%\end{array}$ & $\begin{array}{l}\text { Cronbach's } \\
\alpha\end{array}$ \\
\hline \multicolumn{6}{|l|}{ Green marketing awareness } \\
\hline Environmental Cleanser can reduce environmental pollution & 0.721 & 0.801 & \multirow[t]{8}{*}{5.007} & \multirow[t]{8}{*}{62.584} & \multirow[t]{8}{*}{0.914} \\
\hline Environmental Cleanser is a green product & 0.756 & 0.828 & & & \\
\hline $\begin{array}{l}\text { The production of Environmental Cleanser can reduce the waste } \\
\text { of resources }\end{array}$ & 0.725 & 0.798 & & & \\
\hline Environmental Cleanser meet the concept of carbon reduction & 0.785 & 0.847 & & & \\
\hline $\begin{array}{l}\text { Environmental Cleanser comply with environmental protection } \\
\text { concept }\end{array}$ & 0.685 & 0.759 & & & \\
\hline $\begin{array}{l}\text { Environmental Cleanser enable consumers pay attention on } \\
\text { environmental issues }\end{array}$ & 0.724 & 0.791 & & & \\
\hline Environmental Cleanser can meet social responsibility & 0.651 & 0.728 & & & \\
\hline Using Environmental Cleanser is right behavior & 0.692 & 0.770 & & & \\
\hline \multicolumn{6}{|l|}{ Perceived innovation } \\
\hline Environmental Cleanser is a improvement product & 0.684 & 0.758 & \multirow[t]{5}{*}{5.532} & \multirow[t]{5}{*}{61.463} & \multirow[t]{5}{*}{0.921} \\
\hline Environmental Cleanser has innovation concept & 0.730 & 0.795 & & & \\
\hline The function of Environmental Cleanser has great difference & 0.631 & 0.703 & & & \\
\hline Environmental Cleanser has different design & 0.738 & 0.799 & & & \\
\hline Environmental Cleanser can saving more & 0.701 & 0.765 & & & \\
\hline
\end{tabular}




\begin{tabular}{|c|c|c|c|c|c|}
\hline The cleaning effect of Environmental Cleanser will stronger & 0.703 & 0.767 & & & \\
\hline Environmental Cleanser has a creative promotion method & 0.787 & 0.843 & & & \\
\hline Environmental Cleanser can attracting consumer & 0.744 & 0.809 & & & \\
\hline The innovation idea of Environmental Cleanser is outstanding & 0.743 & 0.809 & & & \\
\hline \multicolumn{6}{|l|}{ Perceived quality } \\
\hline The quality of Environmental Cleanser is superior & 0.807 & 0.880 & \multirow[t]{5}{*}{3.922} & \multirow[t]{5}{*}{78.444} & \multirow[t]{5}{*}{0.930} \\
\hline The quality of Environmental Cleanser is stable & 0.858 & 0.917 & & & \\
\hline The quality of Environmental Cleanser is reliability & 0.870 & 0.924 & & & \\
\hline The quality of Environmental Cleanser is high & 0.862 & 0.919 & & & \\
\hline The quality of Environmental Cleanser is effective & 0.682 & 0.781 & & & \\
\hline \multicolumn{6}{|l|}{ Perceived price } \\
\hline The price of Environmental Cleanser is expensive & 0.824 & 0.907 & \multirow[t]{4}{*}{3.162} & \multirow[t]{4}{*}{79.039} & \multirow[t]{4}{*}{0.911} \\
\hline The price of Environmental Cleanser is costly & 0.857 & 0.926 & & & \\
\hline $\begin{array}{l}\text { The price of Environmental Cleanser is higher than the ordinary } \\
\text { cleanser }\end{array}$ & 0.752 & 0.858 & & & \\
\hline The price of Environmental Cleanser is higher than my expected & 0.761 & 0.864 & & & \\
\hline \multicolumn{6}{|l|}{ Perceived risk } \\
\hline I am afraid that Environmental Cleanser is unvalued & 0.696 & 0.808 & \multirow[t]{6}{*}{3.676} & \multirow[t]{6}{*}{61.263} & \multirow[t]{6}{*}{0.873} \\
\hline $\begin{array}{l}\text { I am afraid that Environmental Cleanser can not meet the } \\
\text { expectation }\end{array}$ & 0.725 & 0.827 & & & \\
\hline I am afraid that Environmental Cleanser cannot ensure its safety & 0.730 & 0.826 & & & \\
\hline $\begin{array}{l}\text { I am afraid that Environmental Cleanser can not to protect my } \\
\text { health }\end{array}$ & 0.682 & 0.787 & & & \\
\hline I am afraid that Environmental Cleanser is useless & 0.579 & 0.695 & & & \\
\hline I am afraid that Environmental Cleanser is ineffectiveness & 0.632 & 0.745 & & & \\
\hline \multicolumn{6}{|l|}{ Perceived value } \\
\hline Environmental Cleanser give me extra value & 0.724 & 0.822 & \multirow[t]{5}{*}{3.631} & \multirow[t]{5}{*}{72.629} & \multirow[t]{5}{*}{0.906} \\
\hline It's worth to pay more money for Environmental Cleanser & 0.759 & 0.849 & & & \\
\hline Environmental Cleanser have high utility & 0.769 & 0.856 & & & \\
\hline Environmental Cleanser can meet my requirements & 0.764 & 0.854 & & & \\
\hline Environmental Cleanser give me more benefits than the costs & 0.798 & 0.879 & & & \\
\hline \multicolumn{6}{|l|}{ Purchase intention } \\
\hline I like to purchase Environmental Cleanser & 0.792 & 0.872 & \multirow[t]{5}{*}{3.813} & \multirow[t]{5}{*}{76.254} & \multirow[t]{5}{*}{0.922} \\
\hline I will pay more money on Environmental Cleanser & 0.765 & 0.852 & & & \\
\hline I will take Environmental Cleanser as a first consideration & 0.802 & 0.877 & & & \\
\hline I will repeat purchasing Environmental Cleanser & 0.875 & 0.925 & & & \\
\hline $\begin{array}{l}\text { I will recommend other people to purchase Environmental } \\
\text { Cleanser }\end{array}$ & 0.750 & 0.838 & & & \\
\hline
\end{tabular}

\subsection{Structural Relationship Analysis}

Testing of the hypotheses in this section was analyzed through inferential statistics and it was tried to find a suitable response for research questions given to confirmation or rejection of hypotheses. Using structural equations models to analysis the causal relationship among the variables then to test the hypothesis was suitable.

This study used AMOS 17.0 software for structural equation modeling (SEM) analysis to understand the relationships among multiple variables and their intensity. According to the principle of the good model: the value of GFI, NFI, RFI and CFI should exceed 0.9 (Joreskog \& Sorbom, 1989); AGFI should exceed 0.8 (Segars \& Grover, 1993), RMSEA should be no more than 0.08 (Browne \& Cudek, 1993), and the ratio of $\chi^{2} / \mathrm{df}$ should be less than 3 (Maciver \& Camines, 1981) to test the fitness of the model. The results of SEM analysis show that the fitness of the full models for both products met or were close to the criteria, so the models were acceptable (as shown in Figures 2 and 3). Meanwhile, the results show that most of the hypotheses are supported, as shown in Table 3. 
$0.202^{*}$

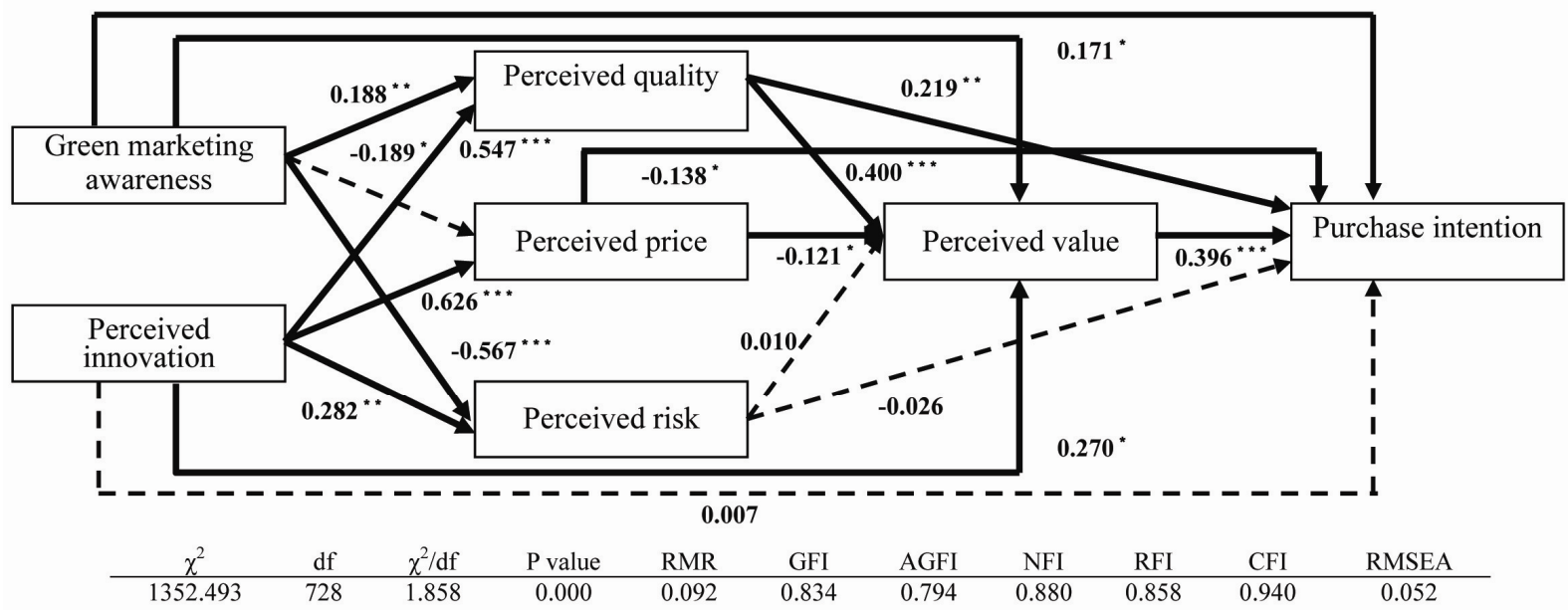

Figure 2. Relationship model of Energy-Saving Lamp

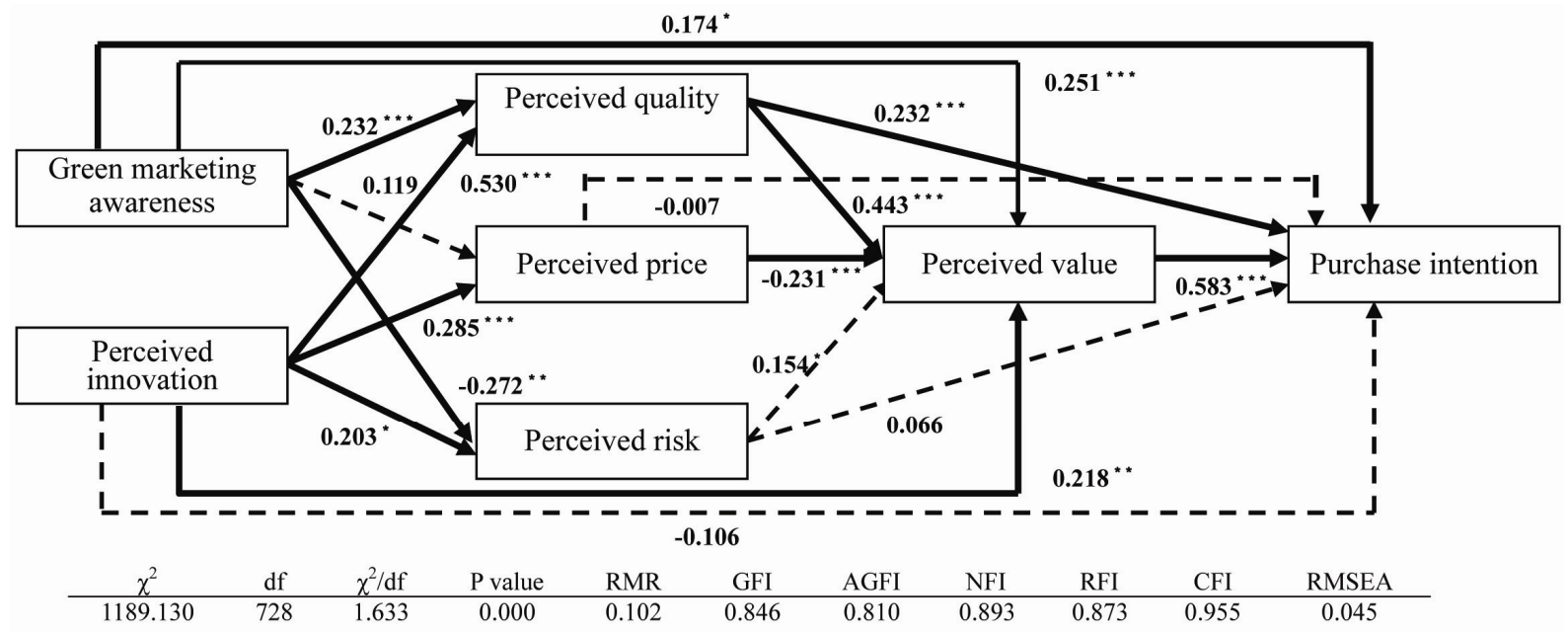

Figure 3. Relationship model of Environmental Cleanser

Table 3. The results of hypotheses test

\begin{tabular}{|c|c|c|}
\hline \multirow{2}{*}{ Research hypotheses } & \multicolumn{2}{|l|}{ Research results } \\
\hline & Energy-Saving Lamp & Environmental Cleanser \\
\hline $\begin{array}{l}\text { H1: Green marketing awareness by consumer toward a green product has a positive } \\
\text { influence on consumer's perceived quality. }\end{array}$ & Supported $\left(++^{* *}\right)$ & Supported $\left(++^{+*}\right)$ \\
\hline $\begin{array}{l}\text { H2: Green marketing awareness by consumer toward a green product has a positive } \\
\text { influence on consumer's perceived price. }\end{array}$ & Rejected(-") & Rejected(n.s) \\
\hline $\begin{array}{l}\text { H3: Green marketing awareness by consumer toward a green product has a negative } \\
\text { influence on consumer's perceived risk. }\end{array}$ & Supported(- & Supported(-" \\
\hline $\begin{array}{l}\text { H4: Green marketing awareness by consumer toward a green product has a positive } \\
\text { influence on consumer's perceived value. }\end{array}$ & Supported(+ $)$ & Supported $\left(+{ }^{+*+4}\right.$ \\
\hline $\begin{array}{l}\text { H5: Green marketing awareness by consumer toward a green product has a positive } \\
\text { influence on consumer's purchase intention. }\end{array}$ & Supported(+ & Supported $\left(+{ }^{*}\right)$ \\
\hline $\begin{array}{l}\text { H6: Consumers perceptions on product innovation will positive influence on consumer's } \\
\text { perceived quality }\end{array}$ & Supported(+ & Supported(+ \\
\hline $\begin{array}{l}\text { H7: Consumers perceptions on product innovation will positive influence on consumer's } \\
\text { perceived price. }\end{array}$ & Supported $\left(+{ }^{*}\right)$ & Supported $\left(+{ }^{+*}\right)$ \\
\hline $\begin{array}{l}\text { H8: Consumers perceptions on product innovation will positive influence on consumer's } \\
\text { perceived risk. }\end{array}$ & Supported(+") & Supported $\left(+^{*}\right)$ \\
\hline $\begin{array}{l}\text { H9: Consumers perceptions on product innovation will positive influence on consumer's } \\
\text { perceived value. }\end{array}$ & Supported(+*) & Supported $\left(+{ }^{*}\right)$ \\
\hline
\end{tabular}




\begin{tabular}{|c|c|c|}
\hline $\begin{array}{l}\text { H10: Consumers perceptions on product innovation will positive influence on consumer's } \\
\text { purchase intention. }\end{array}$ & Rejected (n.s) & Rejected (n.s) \\
\hline $\begin{array}{l}\text { H11: Consumer's perceived quality toward a green product has a positive influence on } \\
\text { consumer's perceived value. }\end{array}$ & Supported(+ & Supported(+ \\
\hline $\begin{array}{l}\text { H12: Consumer's perceived quality toward a green product has a positive influence on } \\
\text { consumer's purchase intention. }\end{array}$ & Supported(+" & Supported $\left(+{ }^{*+*}\right)$ \\
\hline $\begin{array}{l}\text { H13: Consumer's perceived price toward a green product has a negative influence on } \\
\text { consumer's perceived value. }\end{array}$ & Supported(-") & Supported(-") \\
\hline $\begin{array}{l}\text { H14: Consumer's perceived price toward a green product has a negative influence on } \\
\text { consumer's purchase intention. }\end{array}$ & Supported(-") & Rejected (n.s) \\
\hline $\begin{array}{l}\text { H15: Consumer's perceived risk toward a green product has a negative influence on } \\
\text { consumer's perceived value. }\end{array}$ & Rejected (n.s) & Rejected $\left(+{ }^{*}\right)$ \\
\hline $\begin{array}{l}\text { H16: Consumer's perceived risk toward a green product has a negative influence on } \\
\text { consumer's purchase intention. }\end{array}$ & Rejected (n.s) & Rejected (n.s) \\
\hline $\begin{array}{l}\text { H17: Consumer's perceived value toward a green product has a positive influence on } \\
\text { consumer's purchase intention. }\end{array}$ & Supported $\left(+{ }^{*+w^{*}}\right)$ & Supported $\left(+{ }^{*+1}\right)$ \\
\hline
\end{tabular}

This study went further to compare the relationship models of the two products (energy-saving lamp and an environmental cleanser); the results show that three paths differ between two products. The three paths are the influence of green marketing on perceived price, the influence of perceived price on purchase intention, and the influence of perceived risk on perceived value (dotted line in Figure 4). The first difference path shows that consumers' green marketing awareness for energy-saving lamp has a significantly negative impact on the perceived price, but there is no significant impact for the environmental cleanser. Second, consumers' perceived price for energy-saving lamp has a significantly negative impact on the purchase intention, but there is no significant impact for the environmental cleanser. Third, consumers' perceived risk for the environmental cleanser has a significantly positive impact on the perceived value, but there is no significant impact for energy-saving lamp.

With the above exceptions, the paths and direction of the relationships are the same for the two products. The results show that the relationship paths (solid line in Figure 4) for energy-saving lamp and the environmental cleanser have a high degree of similarity. The results also establish a specific and valid relationship model for consumption patterns of green products, which is an important contribution (solid line in Figure 4).

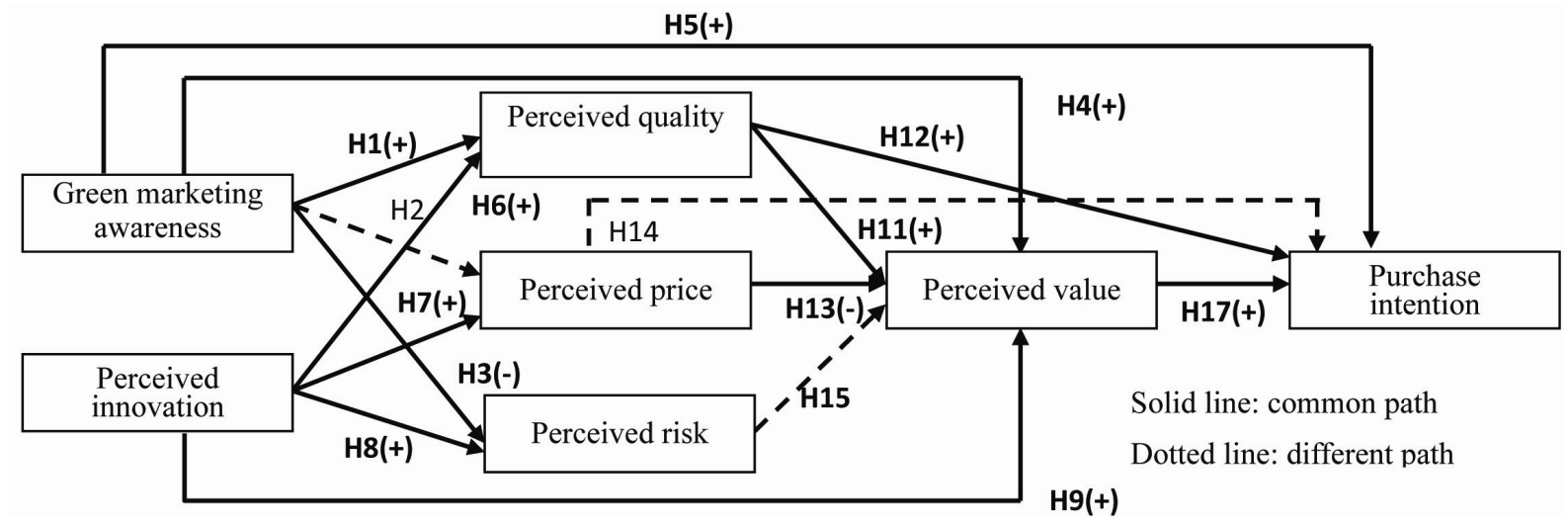

Figure 4. Integration of the common path

\subsection{Influence Effects of Each Aspect}

To compare the effects of consumers' green marketing awareness and perceived innovation on purchase intention, we divided the total influence effect into direct and indirect effects (as shown in Table 4).

Taking energy-saving lamp as an example, the total effect of green marketing awareness on purchase intention is 0.3884 , and the total effect of perceived innovation on purchase intention is 0.1977 . The results show that the effect of green marketing awareness is greater than that of perceived innovation. Thus, the purchase intention for 
energy-saving lamps is majorly dependent on whether the green marketing of the product can be perceived by consumers.

When considering the environmental cleanser, the total effect of green marketing awareness on purchase intention is 0.3748 , and the total effect of perceived innovation on purchase intention is 0.2722 . The results also show that the purchase intention for the environmental cleanser is majorly dependent on whether the green marketing of the product can be perceived by consumers.

Therefore, consumers' green marketing awareness of a green product is a more important factor than perceived innovation in terms of purchase intention, which is another important finding.

Table 4. Analysis of influence effects of each variable

\begin{tabular}{|c|c|c|c|c|c|c|c|c|}
\hline \multirow{2}{*}{$\begin{array}{l}\text { Independent } \\
\text { variables }\end{array}$} & \multirow{2}{*}{$\begin{array}{l}\text { Mediator } \\
\text { variables }\end{array}$} & \multirow{2}{*}{$\begin{array}{l}\text { Dependent } \\
\text { variables }\end{array}$} & \multicolumn{2}{|c|}{ Direct effect } & \multicolumn{2}{|c|}{ Indirect effect } & \multicolumn{2}{|l|}{ Total effect } \\
\hline & & & $\begin{array}{l}\text { Energy-Sa } \\
\text { ving Lamp }\end{array}$ & $\begin{array}{l}\text { Environ-men } \\
\text { tal Cleanser }\end{array}$ & $\begin{array}{l}\text { Energy-Sa } \\
\text { ving Lamp }\end{array}$ & $\begin{array}{l}\text { Environ-men } \\
\text { tal Cleanser }\end{array}$ & $\begin{array}{l}\text { Energy-Sa } \\
\text { ving Lamp }\end{array}$ & $\begin{array}{l}\text { Environ-me } \\
\text { ntal Cleanser }\end{array}$ \\
\hline $\begin{array}{l}\text { Green marketing } \\
\text { awareness }\end{array}$ & & $\begin{array}{l}\text { purchase } \\
\text { intention }\end{array}$ & 0.202 & 0.174 & & & & \\
\hline $\begin{array}{l}\text { Green marketing } \\
\text { awareness }\end{array}$ & perceived quality & $\begin{array}{l}\text { purchase } \\
\text { intention }\end{array}$ & & & 0.0412 & 0.0538 & & \\
\hline $\begin{array}{l}\text { Green marketing } \\
\text { awareness }\end{array}$ & perceived price & $\begin{array}{l}\text { purchase } \\
\text { intention }\end{array}$ & & & 0.0261 & -0.0008 & & \\
\hline $\begin{array}{l}\text { Green marketing } \\
\text { awareness }\end{array}$ & perceived risk & $\begin{array}{l}\text { purchase } \\
\text { intention }\end{array}$ & & & 0.0147 & -0.0180 & & \\
\hline $\begin{array}{l}\text { Green marketing } \\
\text { awareness }\end{array}$ & perceived value & $\begin{array}{l}\text { purchase } \\
\text { intention }\end{array}$ & & & 0.0677 & 0.1463 & & \\
\hline $\begin{array}{l}\text { Green marketing } \\
\text { awareness }\end{array}$ & $\begin{array}{l}\text { perceived quality } \\
\& \text { perceived } \\
\text { value }\end{array}$ & $\begin{array}{l}\text { purchase } \\
\text { intention }\end{array}$ & & & 0.0298 & 0.0599 & & \\
\hline $\begin{array}{l}\text { Green marketing } \\
\text { awareness }\end{array}$ & $\begin{array}{l}\text { perceived price } \\
\& \text { perceived } \\
\text { value }\end{array}$ & $\begin{array}{l}\text { purchase } \\
\text { intention }\end{array}$ & & & 0.0091 & -0.0160 & & \\
\hline $\begin{array}{l}\text { Green marketing } \\
\text { awareness }\end{array}$ & $\begin{array}{l}\text { perceived risk \& } \\
\text { perceived value }\end{array}$ & $\begin{array}{l}\text { purchase } \\
\text { intention }\end{array}$ & & & -0.0022 & -0.0244 & 0.3884 & 0.3748 \\
\hline $\begin{array}{l}\text { Perceived } \\
\text { innovation }\end{array}$ & & $\begin{array}{l}\text { purchase } \\
\text { intention }\end{array}$ & 0.007 & -0.106 & & & & \\
\hline $\begin{array}{l}\text { Perceived } \\
\text { innovation }\end{array}$ & perceived quality & $\begin{array}{l}\text { purchase } \\
\text { intention }\end{array}$ & & & 0.1198 & 0.1230 & & \\
\hline $\begin{array}{l}\text { Perceived } \\
\text { innovation }\end{array}$ & perceived price & $\begin{array}{l}\text { purchase } \\
\text { intention }\end{array}$ & & & -0.0864 & -0.0020 & & \\
\hline $\begin{array}{l}\text { Perceived } \\
\text { innovation }\end{array}$ & perceived risk & $\begin{array}{l}\text { purchase } \\
\text { intention }\end{array}$ & & & -0.0073 & 0.0134 & & \\
\hline $\begin{array}{l}\text { Perceived } \\
\text { innovation }\end{array}$ & perceived value & $\begin{array}{l}\text { purchase } \\
\text { intention }\end{array}$ & & & 0.1069 & 0.1271 & & \\
\hline $\begin{array}{l}\text { Perceived } \\
\text { innovation }\end{array}$ & $\begin{array}{l}\text { perceived quality } \\
\& \text { perceived } \\
\text { value }\end{array}$ & $\begin{array}{l}\text { purchase } \\
\text { intention }\end{array}$ & & & 0.0866 & 0.1369 & & \\
\hline $\begin{array}{l}\text { Perceived } \\
\text { innovation }\end{array}$ & $\begin{array}{l}\text { perceived price } \\
\& \text { perceived } \\
\text { value }\end{array}$ & $\begin{array}{l}\text { purchase } \\
\text { intention }\end{array}$ & & & -0.030 & -0.0384 & & \\
\hline $\begin{array}{l}\text { Perceived } \\
\text { innovation }\end{array}$ & $\begin{array}{l}\text { perceived risk \& } \\
\text { perceived value }\end{array}$ & $\begin{array}{l}\text { purchase } \\
\text { intention }\end{array}$ & & & 0.0011 & 0.0182 & 0.1977 & 0.2722 \\
\hline
\end{tabular}

Note. Total effect $=$ Direct effect + Indirect effect.

\section{Conclusions and suggestions}

\subsection{Conclusions and Discussion}

Through SEM analysis, this study establishes paths and a valid relationship model for green products and includes some important findings. 
There are three paths differ based on the different types of green product; however, almost all the paths are the same for both green products. Therefore, the main relationship paths and relationship model are established as follows (see Table 4):

(1). Consumers' green marketing awareness has significantly positive influence on the perceived quality, perceived value, and purchase intention. The result was consistent with the concepts brought up by Ottman (1999) and Loudon \& Bitta (1988). It indicates that the green marketing perceived by consumers in the green products brought consumers certain quality assurance, and the consumers believed that purchasing green products could satisfy their demand in terms of quality, use, and functions, and they would reduce environmental pollution and the waste of resources, which was worth consumers' purchase. Consequently, the more influence consumers have on green marketing awareness, the higher the overall product value is raised, and the purchase intention will also be enhanced.

(2). This study showed that consumers' green marketing awareness has significantly negative influence on the perceived risk, which was consistent with the hypothesis in this study. The result corresponds to the research such as Bjorner et al. (2004) addressed that the implementation of a green marketing strategy helped consumers identify green products and further obtain trustworthy information as the basis of purchasing products, which indirectly reduced consumers' uncertainty and perceived risk.

(3). Consumers' perceived innovation toward green products has significantly positive influence on the perceived quality, perceived price, perceived risk, and perceived value, which mutually proved the concepts brought up by Roberston (1985), Ram (1989), and Rogers (1995). This indicates that when consumers perceive the innovation of a green product, they will further perceive the quality changes, which strengthens their recognition of quality. Moreover, the perceived innovation has significant influence on the perceived price, indicating that when consumers perceive the innovation of a green product, they will further recognize that the price may increase. Meanwhile, when consumers perceive the innovation of green products, they will perceive uncertainties, such as the unsure value of new products, risk, and negatively stereotyped images, which will increase consumers' perceived risk. Furthermore, the new functions of innovative green products satisfy more consumers' demand, thus, the higher innovation of a green product consumers perceive, the higher the perceived value is.

(4). Consumers' perceived quality has a significantly positive influence on perceived value and purchase intention, which confirms the concepts addressed by Dodds et al. (1991). This indicates that when consumers perceive higher product quality, they also perceive better value, which leads to stronger purchase intention.

(5). Consumers' perceived price has a significantly negative influence on perceived value, which confirms the concepts brought up by Bruce and Abhijit (2002), Oh (1999), and Tam (2004). Therefore, when enterprises carry out sales strategies related to green products, they should consider the pricing of those green products. If the prices are too high, consumers' perceived value will be reduced.

(6). Consumers' perceived value has significantly positive influence on the purchase intention, which mutually proved the concepts brought up by Zeithaml (1988), Kaufman (1998), and Dumana \& Mattilab (2005). The higher consumers' perceived value of green products is, the higher the tendency to have green consumption is. That is, consumers' purchase intention depends on the perceived value of products, and when the perceived value is high, the purchase intention will also be high.

(7). Consumers' perceived risk has not significant influence on the purchase intention. Therefore, if consumers can perceive the green and innovative concepts of a product, the purchase intention will increase due to the raise of the perceived quality and perceived value instead of reducing risk.

(8). According to the comparison between the green marketing awareness and perceived innovation influence on the purchase intention, the result indicates that the green marketing awareness has higher effect than perceived innovation. Therefore, green marketing awareness is most key factor for enhancing consumer's purchase intention of green products. If manufacturers would like to increase consumers' purchase intention of green products, it is better through the perception and feelings provided to consumers by a product's green marketing concept in product, technology, production, and promotion.

\subsection{Managerial Implications}

In this study, not only was the relationship model developed, but measurement variables and a scale were also established, which provide academia and industry with critical research tools and concepts that should be of academic and practical value.

This study found that consumers' green marketing awareness has the maximum influence on purchase intention, 
which indicates that the greater the perception of green marketing of green products, the higher is consumers' purchase intention. In particular, green marketing awareness has the greatest effect on the increase of perceived value. Consequently, it is suggested that enterprises should aim at core consumers and apply green marketing strategies to bring more consumer recognition. In addition, they should further understand the main influences in terms of the effects of green marketing strategies and clearly comprehend consumers' behavioral principles of green consumption, which will help enterprises develop strategies and actions corresponding to current market demand.

The results found that the green marketing awareness of the two products had significantly positive influence on the purchase intention, but the perceived innovation did not. Hence, when consumers purchase green products, they will value and care about the green concept of products. Consequently, manufacturers can aim at their target consumer to provide more green information of the green products in order to attract consumers' attention and enhancing their purchase intention.

The result indicates that green marketing awareness has a greater effect than perceived innovation. Therefore, green marketing awareness is the most important factor for enhancing consumers' purchase intention for green products. Manufacturers can most successfully increase consumers' purchase intention for green products through the perception and feelings they develop through a product's green marketing concept in terms of product, technology, production, and promotion.

\subsection{Study Limitations and Suggestions for Future Study}

This study has delivered valuable results; however, there are still some issues that have to be addressed.

Two separate products used might influence the evaluation of each measurement item. Therefore, the results of this study may not be generalized to all types of green products. Future studies can compare various products, leading to further understanding of the differences between various products. Moreover, future studies can verify the value of the measurement variables and the relationship model.

Green consumers can be divided into different groups, and future studies can segment them accordingly to further investigate their perceived differences in green products, study the various groups' purchase intentions for green products, and develop suitable strategy for the different groups.

Some control variables should be added in the model (for example, age, sex, etc.) that could highlight relevant effects of these variables on the considered factors.

\section{References}

Agarwal, S., \& Teas, R. K. (2001). Perceived value: Mediating role of perceived risk. Journal of Marketing Theory and Practice, 9(4), 1-14.

Ansar, N. (2013). Impact of Green Marketing on Consumer Purchase Intention. Mediterranean Journal of Social Sciences, 4(11), 650-655.

Babin, B. J., Hardesty, D. M., \& Suter, T. A. (2003). Color and shopping intention: The interviewing effect of price fairness and perceived affect. Journal of Business Research, 56(7), 541-551. http://dx.doi.org/10.1016/S0148-2963(01)00246-6

Balderjahn, I. (1988). Personality variables and environmental attitudes as predictors of ecologically responsible consumption patterns. Journal of Business Research, 17(1), 51-56. http://dx.doi.org/10.1016/0148-2963(88)90022-7

Bauer, R. A. (1960). Consumer behavior as risk taking. In R. S. Hancock (Ed.), Dynamic Marketing for a Changing World (pp. 389-398). Chicago: America Marketing Association.

Bei, L. T., \& Yu, C. C. (2001). An integrated model for the effects of perceived product, perceived service quality, and perceived price fairness on consumer satisfaction and loyalty. Journal of Consumer Satisfaction, Dissatisfaction and Complaining Behavior, 14, 125-140.

Bellizzi, J. A. (1981). Consumer perceptions of national private and generic brands. Journal of Retailing, 57(4), 56-70.

Bettman, J. R. (1973). Perceived risk and its components: A model and empirical test. Journal of Marketing Research, 10, 184-190. http://dx.doi.org/10.2307/3149824

Betz, F. (2003). Managing Technological innovation: Competitive Advantage from Change. NJ: John Wiley \& Sons. 
Bjorner, T. B., Hansen, L. G., \& Russell, C. S. (2004). Environmental labeling and consumers choice - An empirical analysis of the effect of the Nordic Swan. Journal of Environmental Economics and Management, 47(3), 411-434. http://dx.doi.org/10.1016/j.jeem.2003.06.002

Boomsma, A., \& Hoogland, J. J. (2001). The robustness of LISREL modeling revisited. Psychometrika, 51, 313-325.

Bourdeau, L., Chebat, J., \& Couturier, C. (2002). Internet consumer value of university students: E-mail v.s. Web users. Journal of Retailing and Consumer Services, 9(2), 61-69. http://dx.doi.org/10.1016/S0969-6989(01)00025-X

Boyd, T. C., \& Mason, C. H. (1999). The link between attractiveness of "Extrabrand" attributes and the adoption of innovations. Journal of the Academy of Marketing Science, 27, 306-319. http://dx.doi.org/10.1177/0092070399273002

Brentani, D. U. (2001). Innovative Versus Incremental New Business Services: Different Keys for Achieving Success. Journal of Product Innovation Management, 18(3), 169-187. http://dx.doi.org/10.1016/S0737-6782(01)00071-6

Browne, M. W., \& Cudek, R. (1993). Alternative Ways of Assessing Model Fit. In K. A. Bollen \& J. S. Long (Eds.), Testing Structural Equation Model (pp. 136-162). Newbury Park, CA: Sage.

Bruce, L. A., \& Abhijit, B. (2002). The effects of discount level, price consciousness and sale proneness on consumers' price perception and behavioral intentions. Journal of Business Research, 55(9), 775-783. http://dx.doi.org/10.1016/S0148-2963(00)00214-9

Brucks, M., \& Zeithaml, V. A. (1991). Price and Brand Name as Indicators of Quality Dimensions. Cambridge. MA: Marketing Science Institute, 91-130.

Bryman, A., \& Bell, E. (2011). Business Research Methods (3rd ed.). New York. Oxford: University Press Inc.

Burst Media. (2010). Nine in 10 Consumers Put "Green" in Daily Routine.

Carmines, E. G., \& Maclver, J. P. (1981). Analyzing Models with Unobserved Variables. In Bohrnstedt, G. W. \& Borgatta, E. F. (Eds.), Social Measurement: Current Issues (pp.65-115). CA: Sage Publications.

Chang, C. L. (2005). Research of the factors that family's users buy the energy-efficient bulb. Unpublished doctoral dissertation, National Sun Yat-sen University, Kaohsiung, Taiwan.

Chase, D., \& Smith, T. K. (1992). Consumers keen on green but marketers don't deliver. Advertising Age, 63, 82-84.

Chaudhuri, A. (2002). How brand reputation affects the advertising-brand equity link. Journal of Advertising Research, 42(3), 33-43.

Chen, C. Y., \& Kao, Y. C. (2005). Development and analysis of a framework for evaluating a green production and consumption system. Journal of Humanities and Social Sciences, 1(1), 1-17.

Chen, Z., \& Dubinsky, A. J. (2003). A conceptual model of perceived customer value in E-commerce. A Preliminary Investigation. Psychology \& Marketing, 20(4), 323-347. http://dx.doi.org/10.1002/mar.10076

Cherian, J., \& Jacob, J. (2012). Green marketing: A study of consumers' attitude towards environment friendly products. Asian Social Science, 8(12), 117-126. http://dx.doi.org/10.5539/ass.v8n12p117

Dagnoli, J. (1991). Consciously green. Advertising Age, 14, 41.

Dangelico, R. M., \& Pontrandolfo, P. (2010). From green product definitions and classifications to the green

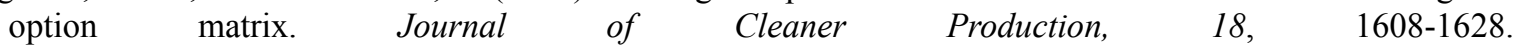
http://dx.doi.org/10.1016/j.jclepro.2010.07.007

Dodds, W. B., Monroe, K., \& Grewal, D. (1991). Effects of price, brand, and store information on buyers' product evaluations. Journal of Marketing Research, 28, 307-319. http://dx.doi.org/10.2307/3172866

Doorn, J. V., \& Verhoef, P. C. (2011). Willingness to pay for organic products: Differences between virtue and vice foods. International Journal of Research in Marketing, 28(3), 167-180. http://dx.doi.org/10.1016/j.jiresmar.2011.02.005

Dumana, T., \& Mattilab, A. S. (2005). The role of affective factors on perceived cruise vacation value. Tourism Management, 26, 321-323.

EnviroMedia Social Marketing. (2010). New Research Shows Green Shoppers Unfazed by Economic Recession. 
Fishbein, M., \& Ajzen, I. (1975). Belief, Attitude, Intention, and Behavior: An Introduction to Theory and Research. MA: Addison-Wesley Publishing Company.

Flint, D. J., Woodruff, R. B., \& Gardial S. F. (1997). Customer value change in industrial marketing relationships. Industrial Marketing Management, 26(2), 163-175. http://dx.doi.org/10.1016/S0019-8501(96)00112-5

Fornell, C., Johnson, M. D., Anderson, E. W., Cha, J., \& Bryant, B. E. (1996). The American customer satisfaction index: nature, purpose, and findings. Journal of Marketing, 60, 1-13. http://dx.doi.org/10.2307/1251898

Freeman, C. (1982). The Economics of Industrial Innovation. MIT Press, 13-20.

Gail, N. K. (2010). Green Marketing: What Works; What Doesn't - A Marketing Study of Practitioners, Environmental Leader.

Garretson, J. A., \& Clow, K. E. (1999). The influence of coupon face value on service quality expectation, risk perceptions and purchase intentions in the dental industry. The Journal of Service Marketing, 13(1), 59-70. http://dx.doi.org/10.1108/08876049910256122

Garvin, D. A. (1988). Management Quality: The Strategic and Competitive Edge. NY: Free Press.

Gaski, J. F., \& Nevin, J. R. (1985). The differential effects of exercised and unexercised power sources in a marketing channel. Journal of Marketing Research, 22, 130-142. http://dx.doi.org/10.2307/3151359

Green Business News. (2010). The Simple Secrets to Successful Green Marketing.

GreenSeal. (2009). 2009 National Green Buying Research.

Grewal, D., \& Levy, M. (2008). Marketing. NY: McGraw-Hill/Irwin.

Grewal, D., Monroe, K. B., \& Krishnan R. (1998).The effects of price-comparison advertising on buyers' perceptions of acquisition value, transaction value, and behavioral intentions. Journal of Marketing, 62(2), 46-59. http://dx.doi.org/10.2307/1252160

Hendershot, S. (2009). Is green enough to lure clients? Crain's Chicago Business, 32(28), 16.

Holak, S. L. (2003). Determinants of innovative durables adoption an empirical study with implications for early product screening. Journal of Product Innovation Management, 19(Sep.), 50-69.

Holak, S. L., \& Lehmann, D. R. (1990). Purchase intentions and the dimensions of innovation: An exploratory $\begin{array}{llll}\text { model. Journal of Product Innovation } & \text { Management, } & 7(1), & \text { 59-73. }\end{array}$ http://dx.doi.org/10.1016/0737-6782(90)90032-A

Horn, D., \& Salvendy, G. (2006). Consumer-based assessment of product creativity: A review and reappraisal. Human Factors and Ergonomics in Manufacturing, 16(2), 155-175. http://dx.doi.org/10.1002/hfm.20047

Hoyer, D., \& Macinnis, D. J. (2010). Consumer Behavior (5th International ed.). Cengage Learning Inc.

Hurley, R. F., \& Hult, G. T. M. (1998). Innovation, market orientation, and organizational learning: An integration and empirical examination. Journal of Marketing, 62, 42-54. http://dx.doi.org/10.2307/1251742

Jacoby, J., \& Kaplan, L. (1972). The components of perceived risk. In Venkatesan, M. (Ed.), Proceedings of the 3rd Annual Conference (pp. 382-393). Illinois: Association for Consumer Research, Champaign.

Joreskog, K. G., \& Sorbom, D. (1989). LISREL 7 user's reference guide. Chicago: Scientific Software.

Kaiser, H. F. (1958). The Varimax criterion for analysis rotation in factor analysis. Psychometrika, 23(3), 187-200. http://dx.doi.org/10.1007/BF02289233

Kaplan, L. B. (1974). Components of perceived risk in product purchase: A cross-validation. Journal of Applied Psychology, 59(3), 287-291. http://dx.doi.org/10.1037/h0036657

Kashyap, R., \& Bojanic, D. C. (2000). A structural analysis of value, quality and price perceptions of business and leisure travelers. Journal of Travel Research, 39, 45-51. http://dx.doi.org/10.1177/004728750003900106

Kassarjian, H. (1971). Incorporating ecology into marketing strategy: The case of air pollution. Journal of Marketing, 61-65. http://dx.doi.org/10.2307/1249791

Kaufman, J. J. (1998). Value Management: Creating Competitive Advantage. In Best Management Practices Series. Menlo Park, CA: Crisp Publications.

Kegerreis, R. J., Engel, J. F., Blackwell, R. D. (1970). Innovativeness and Diffusion: A Marketing View of The 
Characteristics of Earliest Adopters. Research in Consumer Behavior. NY: Holt, Rinhart and Winston.

Kerlinger, F. N. (1978). Foundation of Behavioral Research. NY: McGraw-Hill.

Kotler, P. (1999). Marketing Management (10th ed.). NJ: Prentice-Hall Inc.

Kotler, P., \& Armstrong, G. (2006). Principle of marketing (11 th ed.). NJ: Prentice Hall.

Kotler, P., \& Armstrong, G. (2008). Principles of Marketing (12th ed.). NY: Prentice Hall.

Kwaku, A. G. (1995). An exploratory analysis of the impact of market orientation on new product performance: A contingency approach. Journal of Product Innovation Management, 12(5), 275-293.

Leonidou, C. N., \& Katsikeas, C. S. (2012). "Green" the marketing mix: do firms do it and does it pay off? Journal of the Academy of Marketing Science.

Lim, N. (2003). Consumers' perceived risk: Sources versus consequences. Electronic Commerce Research \& Applications, 2(3), 216-228. http://dx.doi.org/10.1016/S1567-4223(03)00025-5

Lin, H. W. (1996). The study on the delivery effects of green alliances. Unpublished doctoral dissertation, Tatung University, Taipei, Taiwan.

Loudon, D. L., \& Bitta, A. J. D. (1988). Consumer Behavior: Concepts and Application. NY: McGraw-Hill.

MacKenzie, D. (2000). You can still shop to save the world. New Statesman, 129(4468), 12-14.

Makower, J. (2009). Bright Green Marketing Challenge, 3 Nov. 2006. TomPaine.com. 14 July 2009.

Manget, J. (2009). Capturing the Green Advantage for Consumer Companies. The Boston Consulting Group.13 July 2009.

Maxwell, S. (2001). Rule-based price fairness and its effect on willingness to purchase. Journal of Economic Psychology, 23(2), 191-212. http://dx.doi.org/10.1016/S0167-4870(02)00063-6

McKnight, D. H., \& Chervany N. L. (2002). What trust means in e-commerce customer relationship: An interdisciplinary conceptual typology. International Journal of Electronic Commerce, 6(2), 35-59.

Monroe, K. B. (1990). Pricing: Making Profitable Decisions. NY: McGraw-Hill Book Co.

Monroe, K. B., \& Krishnan, R. (1985). The Effect of Price on Subjective Product Evaluations. In J. Jacoby \& J. Olson (Eds.), Perceived Quality (pp. 209-232). Lexington, MA Lexington Books.

Morris, L., Hastak, M., \& Mazis, M. (1995). Consumer comprehension of environmental advertising and labeling claims. The Journal of Consumer Affairs, 29(2), 328-350. http://dx.doi.org/10.1111/j.1745-6606.1995.tb00050.x

Morwitz, V. G., \& Schmittlein, D. (1992). Using segmentation to improve sales forecasts based on purchase intent: which interders actually buy? Journal of Marketing Research, 29(4), 391-405. http://dx.doi.org/10.2307/3172706

NPD. (2010). Apple Owners Nearly 40 Percent More Interested in the iPad than Non-Apple Owners. Port Washington, New York, March 26, 2010.

Nunnally, J. C. (1978). Psychometric Theory. NY: Mcgraw-Hill.

OECD (2009). Responses to the Economic Crisis: Investing in Innovation for Long-Term Growth.

Oh, M. (1999). Service quality, customer satisfaction, and customer value: A holistic perspective. Hotel Management, 18, 67-82.

Olson, J. C., \& Jacoby, J. (1977). Consumer Response to Price: An Attitudinal, Information Processing Perspective. In Y. Wind \& M. G. Grenberg (Eds.), Moving Ahead with Attitude Research (pp. 73-86). Chicago: America Marketing Association.

Ottenbacher, M., \& Gnoth, J. (2005). How to develop successful hospitality innovation? Cornell Hotel and Restaurant Administration Quarterly, 46(2), 205-222. http://dx.doi.org/10.1177/0010880404271097

Ottman, J. A. (1999). Green Marketing: Opportunity for innovation, Chapter 2, Consumer with a conscience. NTC: Contemporary Publishing Company. Retrieved From http://www.greenmarketing.com/Green_Marketing_Book/Chapter02.html

Ottman, J. A., Stafford, E. R. \& Hartman, C. L. (2006). Green marketing myopia. Environment, 48(5), 22-36. http://dx.doi.org/10.3200/ENVT.48.5.22-36 
Petrick, J. F. (2002). Development of multi-dimensional scale for measuring the perceived value of a service. Journal of Leisure Research, 34(2), 119-134.

Petrick, J. F. (2004). First timers' and repeaters' perceived value. Journal of Travel Research, 43(1), 29-38. http://dx.doi.org/10.1177/0047287504265509

Polonsky, M. J. (2011). Transformative green marketing: Impediments and opportunities. Journal of Business Research, 64(12), 1131-1319. http://dx.doi.org/10.1016/j.jbusres.2011.01.016

Porter, M. E. (1990). The Competitive Advantage of Nations. NY: Free Press.

Porter, M. E., \& Van der Linde, C. (1995). Green and competitive. Harvard Business Review, 73(5), 120-134.

Ram, S. (1987). A model of innovation resistance. In M. Wallendorf \& P. F. Anderson (Eds.), Advances in Consumer Research, 14(1), 208-212.

Ram, S. (1989). Successful innovation using strategies to reduce consumer resistance: An empirical test. Journal of Product Innovation Management, 6(1), 20-34. http://dx.doi.org/10.1016/0737-6782(89)90011-8

Ram, S., \& Sheth, J. N. (1989). Consumer resistance to innovations: the marketing problem and its solutions. The Journal of Consumer Marketing, 6(2), 5-14. http://dx.doi.org/10.1108/EUM0000000002542

Rizwan, M., Aslam, A., Rahman, M., Ahmad, N., Sarwar, U., \& Asghar, T (2013). Impact of green marketing on purchase intention: An empirical study from Pakistan. Asian Journal of Empirical Research, 3(2), 87-100.

Roberston, T. S. (1985). Consumer Behavior. Illinois: Scott and Fresman.

Rogers, E. M. (1962). Diffusion of Innovation (3rd ed.). NY: The Free Press.

Rogers, E. M. (1995). Diffusion of Innovation (4th ed.). NY: The Free Press.

Roselius, T. (1971). Consumer rankings of risk reduction methods. Journal of Marketing, 35(1), 56-61. http://dx.doi.org/10.2307/1250565

Segars, A. H., \& Grover, V. (1993). Re-examining perceived ease of use and usefulness: a confirmatory factor analysis. MIS Quarterly, 17, 517-522. http://dx.doi.org/10.2307/249590

Sheth, J. N. (1981). Psychology of innovation resistance. Research in Marketing, 4, 273-282.

Sheth, J. N., Newman, B. I., \& Gross, B. L. (1991). Consumption Values and Market Choices: Theory and Applications. Cincinnati. OH: Southwestern Publishing.

Shimp, T. A., \& Bearden, W. O. (1982). Warranty and other extrinsic cue effects on consumers risk perception. Journal of Consumer Research, 9, 38-46. http://dx.doi.org/10.1086/208894

Shiu, E., Hair, J., Bush, R., \& Ortinau, D. (2009). Marketing Research. London: McGraw-Hill Higher Edition.

Shrivastava, P. (1994). Castrated environment: greening organization studies? Organization Studies, 15(5), 705. http://dx.doi.org/10.1177/017084069401500504

Simon, F. L. (1992). Marketing green products in the triad. The Columbia Journal of World Business, 268-285.

Steenkamp, J. B. (1990). Conceptual model of the quality perception process. Journal of Business Research, 22, 309-333. http://dx.doi.org/10.1016/0148-2963(90)90019-A

Suter, T. A., \& Hardesty, D. M. (2005). Maximizing earnings and price fairness perceptions in online consumer-to-consumer auctions. Journal of Retailing, 81(4), 307-317. http://dx.doi.org/10.1016/j.jretai.2005.01.007

Swan, J. E., \& Nolan, J. J. (1985). Gaining customer trust: A conceptual guide for the salesperson. Journal of Personal Selling and Sales Management, 39-48.

Sweeney, J. C., \& Soutar, G. N. (2001). Consumer perceived value: The development of a multiple item scale. Journal of Retailing, 77, 203-220. http://dx.doi.org/10.1016/S0022-4359(01)00041-0

Sweeney, J. C., Soutar G. N., \& Johnson, L. W. (1999). The role of perceived risk in the quality-value relationship: A study in a retail environment. Journal of Retailing, 75(1), 77-105. http://dx.doi.org/10.1016/S0022-4359(99)80005-0

Tam, L. M. (2004). Customer satisfaction, service quality and perceived value: An integrative model. Journal of Marketing Management, 20(7), 897-917. http://dx.doi.org/10.1362/0267257041838719

Taylor, J. W. (1974). The role of risk in consumer behavior. Journal of Marketing, 38, 54-60. http://dx.doi.org/10.2307/1250198 
TerraChoice Group Inc. (2009). The Seven Sins of Greenwashing. Summary Report North America.

TNS. (2008). Our Green World: An international survey covering 17 countries into how green we really are. London: Kantar Group Company.

Tsai, D. C., \& Lee, C. H. (1999). Relationships between Consumer Characteristics and Internet Shopping Intention. Journal of Management, 16(4), 557-580.

Tsai, D. C., Lee, C. H., \& Wu, W. Y. (2004). The effect of price, warranty and country-of-origin image on product evaluation and purchasing intention. Journal of Management, 21(1), 21-46.

Tsai, M. T., Chuang , L. M., Chen, C. C., \& Chao, H. M. (2010). The research on the relationship among service innovation, normative evaluation, service quality and customer satisfaction-A case study of Taiwan car-rental carrier. Journal of Quality, 17(3), 207-227.

Tsiotsou, R. (2006). The Role of perceived product quality and overall satisfaction on purchase Intentions. $\begin{array}{lllll}\text { International Journal of Consumer } & \text { Studies, } & 30(2), & \text { 207-217. }\end{array}$ http://dx.doi.org/10.1111/j.1470-6431.2005.00477.x

Tu, J. C. (2002). Product Sustainable Design: Green Design in Theory and Practice. Taipei: Asiapac Books Pte Ltd.

Weerawardena, J. (2003). The role of marketing capability in innovation-based competitive strategy. Journal of Strategy Marketing, 11(1), 15-35. http://dx.doi.org/10.1080/0965254032000096766

Wood, C. M., \& Scheer, L. K. (1996). Incorporating perceived into models of consumer deal assessment and purchase intent. Advances in Consumer Research, 23(1), 399-404.

Yan, I. H., \& Chang, Y. W. (2006). The Consumers Cognition of Green Package. Journal of Oriental Institute of Technology, 26, 143-150.

Zeithaml, V. A. (1988). Consumer perceptions of price, quality, and value: A means-end model and synthesis of evidence. Journal of Marketing, 52, 2-22. http://dx.doi.org/10.2307/1251446

Zeithaml, V. A., \& Bitner, M. J. (2000). Services marketing. Boston: Irwin/McGraw-Hill.

\section{Copyrights}

Copyright for this article is retained by the author(s), with first publication rights granted to the journal.

This is an open-access article distributed under the terms and conditions of the Creative Commons Attribution license (http://creativecommons.org/licenses/by/3.0/). 